\title{
Erratum to: Selective Estrogen Receptor Modulators and the Tissue-Selective Estrogen Complex: Analysis of Cell Type-Specific Effects Using In Vivo Imaging of a Reporter Mouse Model
}

\section{Sara Della Torre and Paolo Ciana}

\section{Erratum to:}

Chapter 23 in: Kathleen M. Eyster (ed.), Estrogen Receptors: Methods and Protocols, Methods in Molecular Biology, https://doi.org/10.1007/978-1-4939-3127-9_23

The first name and surname of the author (Sara Della Torre) appeared incorrectly on all websites. This has been corrected.

The updated online version of this chapter can be found at

https://doi.org/10.1007/978-1-4939-3127-9_23 